\title{
Asas Pembuktian Terbalik dalam Penyelesaian Kasus Kejahatan Korupsi
}

\author{
M. Abdul Kholiq, AF.
}

\section{Abstract}

Universally, corruption have been comprehended as a extremely serious crime and it has multidimensional impact so that it caused the state social life becomes abnormal because of the 'serious' corruptive level. Therefore, it needs to be handled braverly in' applying various kinds of strategy both for the common cases and 'abnormal' ones. One of abnomal strategy in the frame of coping with the crime of corruption depicted above is the need of reverse authentication principle in order to make easy in solving the process of case solution and accelerate the effort of rescuing on the state financial and economy. In the theory perspective, although the idea of application on reverse authentication principle has justificative principles and it produces confrontative problems with the various principles else which is established in the doctrine of the material criminal law as well as formal one recently. By this writing, it may be seen as the effort to describe the problem as well as the urgency of idea on reverse authentication principle and then it tries to offer solution about how is the better way of the idea responded in the policy of coping with the comption for the future.

\section{Pendahuluan}

Dalam. salah 'satu butir mengenai konsideran lahirnya UU No. 20 Tahun 2001 tentang Perubahan atas UU No. 31 Tahun 1999 yang mengatur mengenai Pemberantasan Tindak Pidana Korupsi, disebutkan bahwa tindak pidana korupsi perlu digolongkan sebagai kejahatan yang pemberantasannya. harus dilakukan secara luar biasa. Pandangan tersebut adalah didasarkan atas kenyataan bahwa korupsi yang terjadi secara sistematik dan meluas selama ini, tidak hanya telah. merugikan keuangan dan perekonomian negara, tetapi juga merupakan pelanggaran serius terhadap hak-hak sosial dan ekonomi

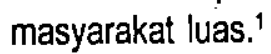

Dampak serius dari kejahatan korupsi sebagaimana sinyalemen di atas, setidaknya tercermin dalam berbạgai analisa yang menyimpulkan bahwa salah satu fakttor penyebab utama "kebangkrutan" ekonomi Indonesia yang belum pulih hingga sekarang ini ialah terjadinya praktek korupsi yang sudah sedemikian "membudaya" dan sistematis baik di kalangan birokrat sebagai pelaksana

'Lihat bagian "Menimbang"/Konsideran huruf a UU No. 20 Tahun 2001 tentang Perubahan atas UU No. 31 Tahun 1999 tentang Pemberantasan Tindak Pidana Korupsi. 
pemerintahan maupun masyarakat pada umumnya. ${ }^{2}$ Oleh sebab itu wajar jika agenda utama yang dituntut mahasiswa pada awal reformasi ketika itu (1998) ialah pemberantasan dan penuntasan kasus-kasus korupsi khususnya dan KKN pada umumnya. Hal demikian ini karena masalah korupsi sudah dipandang sébagai patologi sosial yang sangat kronis. ${ }^{3}$

Secara yuridis, berbagai macam perundang-undangan tentang korupsi sebagai wujud formal political will pemerintah untuk memerangi kejahatan tersebut, sesungguhnya sudah banyak dilahirkan. Bahkan dalam waktu dua tahun terakhir saja,
Indonesia telah mensahkan dua undangundang sekaligus yakni UU No.31 Tahun 1999 yang kemudian beberapa ketentuan yang ada di dalamnya mengalami amandemen melalui UU No.20 Tahun 2001.

Apabila pernyataan salah satu butir konsideran UU No. 20 Tahun 2001 sebagaimana telah dikemukakan terdahulu disimak kembali secara cermat, maka label yang dikenakan terhadap fenomena korupsi di Indonesia dengan status sebagai "kejahatan luar biasa" tersebut, sesungguhnya mengisyaratkan bahwa korupsi benar-benar telah menjadikan negara ini berada dalam keadaan "tidak normal" alias "darurat". ${ }^{4}$ Oleh

2Perhatikan misalnya kumpulan pendapat analitis tentang dampak korupsi yang dirangkum oleh Munawar Fuad Noeh. 1997. Islam dan Gerakan Moral Anti Korupsi, Jakarta: Penerbit Zikrul Hakim. HIm. 56-61. Lihat juga Syed Hussein Al-Attas. 1986. Sosiologi Korupsi: Sebuah Penjelajahan dengan Data Kontemporer. Jakarta: Penerbit LP3ES. HIm. 34. la antara lain menyatakan bahwa salah satu bahaya korupsi jika sudah sampai pada "stadium"/tingkat "keparahan" yang ketiga (ia menganalisa setidaknya ada tiga stadium bahaya korusi-pen.) ialah dapat menghancurkan seluruh sendi dari bangunan suatu masasyarakat.

${ }^{3}$ Sebagai gambaran untuk menunjukkan betapa seriusnya praktek korupsi yang telah terjadi sehingga ia harus menjadi musuh bersama dan utama dari seluruh masyarakat Indonesia, antara lain dapat disimak laporan dari riset-riset yang selalu diterbitkan secara berkala oleh lembaga independen bernama "The Political and Economic Risk. Consultancy Ltd. (PERC)" yang berkedudukan di Hongkong. Laporan dari lembaga ini seringkali diakses dan dipublikasikan oleh berbagai media baik nasional maupun internasional. Sekedar untuk melacak "pertumbuhan" korupsi di Indonesia dalam beberapa tahun terakhir ini, antara lain dilaporkan oleh lembaga tersebut bahwa pada tahun 1995, Indonesia (bersama dengan China) adalah merupakan negara paling korup kedua di Asia setelah posisi pertama ditempati India. Namun dua tahun kemudian (1997), perkembangan korupsi di Indonesia telah melambunikkan negara ini dalam posisi sebagai negara paling korup pertama di Asia, dan ranking kedua sertaketiga jusru ditempati oleh negara India dan China. Untuk data ini, lihat Forum Keadilan. Edisi No.7 tahun VI, tanggal 14 Juli 1997. Selanjutnya, dalam tiga tahun kemudian (akhir 2000), masih menurut PERC, ternyata perkembangan pesat korupsi di Indonesia telah menjadikan negara ini merasa layak ikut "berkompetisi" pada tingkat yang lebih tinggi dan memperoleh "hasil" sebagai negara paling korup ketiga sedunia setelah Kamerun dan Nigeria. Lihat Suara Merdeka .22 Maret 2001.

"Dalam perspektif etimologis, istilah lain dari kata "luar biasa" ialah "tidak normal" atau "darurat". Sebab sesuatu yang biasa adialah sesuatu yang normal atau tidak darurat. Oleh karena itu, jika korupsi dinyatakan sebagai kejahatan yang luar biasa, maka itu artinya sama dengan korupsi merupakan kejahatan yang sangat serius dan telah menimbulkan hal-hal yang tidak biasa, tidak normal alias darurat. Lihat W.J.S Poerwadarminta. 1978. Kamus Umum Bahasa Indonesia. Jakarta: Penerbit Balai Pustaka. Him.230, 609 dan 678. 
karena itu, penanganan terhadap korupsi sebagai sumber abnormalitas atau keadaan darurat inipun tidak boleh bersifat biasa alias tharus dengan cara berpikir dan bertindak darurat pula. Bahkan harus pula ditopang oleh kualitas aparat penegak hukum yang mampu: dan berani melakukan terobosan yang bersifat darurat. Dalam konfigurasi berpikir yang demikian ini, kiranya dapat dipahami jika ada sebagian pakar yang menghendaki bahwa sudah waktunya bangsa Indonesia mencanangkan bahaya korupsi sebagai suatu keadaan darurat. $^{5}$

Adapun salah satu emergency exit atau pintu darurat yang perlu dilalui sebagai terobosan hukum terhadap prinsip-prinsip "konvensonal" itu ialah diterapkannya gagasan tentang sistem atau asas pembuktian terbalik dalam proses penyelesaian kasus korupsi. Artinya, tersangka atau terdakwa harus membuktikan bahwa dirinya tidak bersalah melakukan tindak pidana korupsi seperti yang dituduhkan oleh Jaksa Penuntut Umum. Implikasi yuridisnya ialah jika ia tidak mampu melakukan hal itu maka ia dianggap benarbenar telah melakukan korupsi dan dapat segera dijatuhi sanksi pidana tertentu.

Berdasarkan background historis tentang munculnya kembali gagasan di atas, harus diakui bahwa keinginan untuk menerapkan asas tersebut memang diwarnai pula oleh konsep "menempuh jalan pintas"' setelah banyak orang dari beṛbagai kalangan merasakan kejahatan korupsi di Indonesia tampak semakin merajalela dari hari ke hari. ${ }^{6}$ Walaupun tentu ada alasan-alasan lain yang bersifat lebih mendasar. Misainya karena para koruptor umumnya adalah orang-orang yang memiliki kecakapan intelektual dan berpengalaman, berada dalam lingkup jaringan birokrasi yang kompleks dan sulit ditembus, serta ada kecenderungan untuk saling menutupi. Pendek kata, salah satu kesulitan mendasar yang dirasakan dalam usaha memberantas kejahatan korupsi selama ini ialah terletak pada masalah pembuktian. ${ }^{7}$ Bahkan ada sinyalemen pula yang mengindikasikan bahwa munculnya

${ }^{5}$ Achmad Ali. "Korupsi dan Asas Pembuktian Terbalik." Kompas. 3 April 2001. Perhatikan juga statement beberapa tokoh lain yang pernah dimuat di berbagai media seperti pakar sosiologi hukum Satjipto Rahardjo, mantan Hakim Agung Adi Andojo Soetjipto dan lain-lain yang sudah "geregetan" terhadap cara penanganan korupsi di Indonesia selama ini.

${ }^{6}$ Sekalipun gagasan mengenai perlunya penerapan asas pembuktian terbalik ini bukan hal yang baru sama sekali, namun harus diakui bahwa ia dapat kembali menjadi wacana publik terutama sejak Gus Dur yang pada waktu itu masih menjabat sebagai Presiden RI mengemukakan hal tersebut saat menyampaikan Pidato Pengantar Jawaban atas Memorandum I DPR RI di hadapan Sidang Paripurna dewan tạnggal 28 Maret 2001. Pada waktu itu, Gus Dur bahkan berkeinginan untuk menerbitkan produk hukum berupa PERPU sebagai wadah legitimasi bagi penerapan asas pembuktian terbalik tersebut. Hal ini menunjukkan betapa saat itu korupsi sudah dipandang sedemikian rupa "menjengkelkan" sehingga harus cepat-cepat ditangảni dengan cara-cara yang mengesankan adanya penggunaan jalan pintas. Sebab jika tidak demikian, tentu wadah hukumnya tidak perlu diusulkan dengan menggunakan PERPU melainkan UU biasa.

'Lihat analisis Badan Pengawasan Keuangan dan Pembangunan (BPKP) dalam buku laporan tahunannya. BPKP. 1999. Strategi Pemberantasan Korupsi Nasional. Jakarta: BPKP. HIm. 142-149. 
gagasan tersebut sebenarnya lebih karena didorong oleh keinginan untuk mencontoh beberapa negara jiran/tetangga (seperti Malaysia dan Singapura) yang cukup "sukses" menekan laju korupsi di negaranya sejak menerapkan asas tersebut.

Terlepas dari berbagai latar belakang mengenai ide penerapan asas pembuktian terbalik di atas, yạng pasti, dalam wacana akademik ide tersebut patut memperoleh diskusi "tajam". Karena selain persoalan urgensi, sesungguhnya ide tersebut sarat dengan problem-problem konfrontatif dengan berbagai asas lain yang selama ini telah dianggap sebagai doktrin mendasar dalam ajaran hukum pidana baik materiel maupun formil. Misalnya bagaimana kaitan asas tersebut dengan prinsip presumption of innocence? Bagaimana pula hubungannya dengan prinsip universal yang juga telah ditegaskan dalam Pasal 66 KUHAP bahwa tersangka atau terdakwa tidak dibebani kewajiban pembuktian? Karena yang berkewajiban membuktikan suatu tuduhan ialah pihak yang menuduh/mendakwa (c.q Jaksa Penuntut Umum).

\section{Penerapan Asas Pembuktian Terbalik dan Problematikanya}

Rene Descartes, seorang ahli filsafat terkemuka pada abad ke-17 pernah mengatakan bahwa siapa yang menyatakar: sesuatu maka ia harus membuktikannya (he who asserts must prove).$^{8}$ Berdasarkan pandangan ini, "maka telah diterima sebagai asas yang universal dalam hukum pidana bahwa siapapun yang menuduh ia pula yang harus membuktikan tuduhannya itu. Oleh karenanya, dalam Kitab Undang-undang Hukum Acara Pidana (KUHAP) Indonesia, Jaksa Penuntut Umum yang tugas pokoknya antara lain melakukan penuntutan kepada seseorang yang diduga terlibat suatu tindak pidana dengan cara membuat surat dakwaan dan melimpahkannya ke pengadilan, maka prinsipnya jaksa itu pula yang harus membuktikan dakwaannya. Dengan kata lain, si terdakwa sama sekali tidak dibebani kewajiban untuk membuktikan apa yang dituduhkan oleh jaksa kepada dirinya ataupun membuktikan hal yang sebaliknya. ${ }^{9}$

Prinsip KUHAP di atas merupakan manifestasi dari dianutnya asas fundamental lain yang juga menjadi basis hukum acara pidana Indonesia yakni berupa Presumption of Innocence Principle (Asas Praduga tak Bersalah). ${ }^{10}$ Asas ini mengajarkan bahwa apapun tuduhan yang dikenakan terhadap seseorang, ia wajib dianggap tidak pernah bersalah selama belum ada putusan pengadilan yang berkekuatan hukum tetap yang menyatakan bahwa ia memang bersalah

${ }^{8}$ Rene Descartes sebagaimana dikutip oleh J. Guwandi. "Pembuktian Terbalik." Kompas 7 April 2001.

'Lihat ketentuan Pasal 66 UU No. 8 Tahun 1981 tentang Kitab Undang-undang Hukum Acara Pidana (KUHAP. Lihat juga uraian mengenai prinsip ini pada tulisan Darwan Prinst. 2002. Hukum Acara Pidana dalam Praktek. Cetakan Ketiga (edisi revisi). Jakarta: Penerbit Djambatan bekerjasama dengan YLBHI. HIm. 20.

${ }^{10} \mathrm{Lihat}$ Penjelasan pasal $66 \mathrm{KUHAP}$. 
sebagaimana isi tuduhan yang diarahkan kepadanya itu. "11

Apabila gagasan mengenai asas pembuktian terbalik jàdi-dilegitimasj' secara yuridis dan diterapkan dalam praktek (walaupun masih sebatas pada kasus kejahatan tertentu yakni korupsi), maka kebijakan demikian ini pada hakikatnya merupakan pengingkaran nyata terhadap dianutnya asas praduga tak bersalah. Sebab konstruksi berpikir yang terbangun dalam asas pembuktian terbalik selalu menempatkan asumsi bahwa tersangka/terdakwa adalah orang yang memang bersalah telah melakukan suatu tindak pidana (c.q korupsi). la baru dapat bebas dari asumsi tersebut jika mampu membuktikan sebaliknya bahwa tuduhan/ dakwaan itu tidak benar. Dalam perspektif teori, asumsi dasar yang demikian ini dikenal dengan asas presumption of guilt (praduga bersalah).

Menurut H.L Packer, penyelesaian suatu perkara pidana dengan menggunakan asas praduga bersalah seperti di atas, sesungguhnya dapat memberikan hasil berupa pengendalian kejahatan secara cepat dan tepat, yang pada akhirnya dapat menjamin hak asasi manusia secara keseluruhan dalam masyarakat. Namun demikian, harus diakui bahwa penerapan asas tersebut memang mengandung suatu kelemahan, yakni jika kemampuan dan integritas moral para petugas hukum tidak dapat diandalkan, maka penyelesaian perkara akan menimbulkan berbagai ekses. Misalnya terjadinya "perkosaan" terhadap hak asasi manusia bagi pihak yang terlibat perkara pidana (c.q tersangka/terdakwa)..$^{12}$

Gagasan penerapan pembuktian terbalik yang berbasis pada asas presumption of guilt tersebut, sebenarnya memang sangat rentan/ potensial bagi terjadinya penyalahgunaan kewenangan oleh penyidik atau penuntut umum, sehingga pada akhirnya dapat melahirkan pelanggaran HAM. Sebab penyidik tanpa bukti awal yang cukup dapat saja menjadikan seseorang sebagai tersangka, lalu ditahan, dan kemudian jaksa penuntut umum dapat langsung mendakwa dan melimpahkan perkara orang tersebut ke pengadilan tanpa perlu membuktikan apa yang didakwakan, karena pembuktiannya dibebankan kepada terdakwa. Jika demikian halnya, maka bukan mustahil asas pmbuktian terbalik ini dalam tahap implementasi dapat menjadi modus baru bagi aparat penegak hukum untuk melakukan "pemerasan" kepada setiap orang yang sedang diduga terlibat suatu. perkara pidana. Jadi dengan kata lain penerapan asas ini dimungkinkan justru dapat mempersubur praktek-praktek korupsi atau KKN gaya baru dan bukan menanggulanginya sebagaimana

"Dalam KUHAP, dianutnya asas praduga tak bersalah di atas memang tidak dinyatakan secara eksplisit. Ketentuan tersebut adalah terdapat di dalam pasal 8 UU No. 14 Tahun 1970 tentang Pokok-Pokok Kekuasaan Kehakiman yang sekarang telah dirubah menjadi UU No. 35 Tahun 1999.

${ }^{12}$ H.L Packer dalam Bambang Poernomo. 1984. Orientasi Hukum Acara Pidana Indonesia. Yogyakarta: Bagian Penerbitan Fakultas Hukum Universitas Gadjah Mada. HIm. 196. 
yang diharapkan bersama. ${ }^{13}$ Terlebih lagi dalam situasi kondisi sekarang di mana jajaran aparat penegak hukum masih diindikasikan sebagai "sarang mafia peradilan".

Dalam kasus korupsi, berdasarkan asas pembuktian terbalik ini, setiap orang yang dianggap memiliki harta kekayaan secara tidak wajar atau melebihi penghasilan normal, dapat saja menjadi "target operasi" petugas hukum dengan cara ditetapkan sebagai tersangka/terdakwa. Selanjutnya petugas hukum (c.q penyidik atau penuntut umum atau bahkan hakim) tersebut tidak perlu repot dan cukup menonton saja jalannya persidangan untuk menyimak sejauhmana terdakwa dapat membuktikan hal yang sebaliknya dari tuduhan yang dikenakan. Dalam posisi seperti inilah mereka dengan mudah dapat melakukan "perdagangan hukum" dengan tersangka/terdakwa.

Selanjutnya, jika tersangka/terdakwa tidak mau kompromi dengan tawaran "harga hukumn dari petugas, maka ia harus bekerja keras untuk membuktikan bahwa harta yang dituduhkan kepadanya sebagai hasil korupsi itu adalah benar-benar berasal dari sumber yang sah (legal). Namun, jika akhirnya ia tidak cukup memiliki saksi atau bukti lain mengenai hal itu, maka ia pun dengan mudah akan masuk "perangkap" hukum dan kemudian menjadi seorang terpidana.

Sementara itu, seandainya orang yang terlanjur dituduh sebagai koruptor tersebut ternyata mampu membuktikan bahwa tuduhan itu tidak benar dan oleh karenanya ia kemudian diputus bebas, maka putusan inipun tidak akan mampu secara mudah dan cepat merehabilitasi nama baiknya yang sudah tercemar akibat tuduhan korupsi tadi.

Jadi, sekalipun disadari bahwa penerapan asas pembuktian terbalik untuk menyelesaikan kasus korupsi yang dikenal sangat rumit dan sulit ini pada satu sisi memang relevan dan penting. Terlebih lagi jika dilandasi tujuan untuk mempercepat langkah-langkah penyelematan keuangan/perekonomian negara yang dapat terancam "bangkrut" akibat korupsi. Pada sisi yang lain, asas tersebut ternyata juga potensial untuk dapat "melahirkan" berbagai macam persoalan hukum baru seperti HAM dan keadilan, korupsi atau KKN gaya baru.

Oleh karena itu, dalam rangka merumuskan konsep tentang regulasi hukum yang mampu menampung gagasan penerapan asas pembuktian terbalik dalam perundangundangan yang "ideal" di masa mendatang, kiranya mutlak harus dipertimbangkan berbagai aspek yang menyertainya baik nyata maupun yang masih bersifat predictable. Sehubungan dengan kepentingan tersebut, maka berikut ini patut pula disimak terlebih dahulu bagaimana perundang-undangan korupsi yang ada dan berlaku sekarang telah mengatur masalah pembuktian terbalik ini.

\section{Asas Pembuktian dalam UU Korupsi}

Pada saat UU No. 31 Tahun 1999 tentang Pemberantasan Korupsi masih berbentuk RUU, banyak kalangan berharap agar pada

${ }^{13}$ Perhatikan misalnya pendapat Trimoelja D. Soerjadi. "Pembuktian Terbalik Untuk Memberantas KKN?". Kompas. 9 April 2001. 
waktu disahkań nanti undang-undang tersebut benar-benar memuat berbagai ketentuan baru sebagai refleksi terhadap tuntutan reformasi yang turut mendorong kelahirannya. Salah satu di antara ketentuan baru yang. sangat diharapkan itu ialah adanya pengaturan mengenai asas pembuktian terbalik. ${ }^{14}$ Namun, setelah undang-undang tersebut dinyatakan sah berlaku sejak tanggal 16 Agustus 1999 melalui Lembaran Negara Republik Indonesia Tahun 1999 Nomor $140,{ }^{15}$ kenyataannya tidak ada penegasan yang eksplisit mengeriai pengaturan asas tersebut. Jadi, dengan kata lain UU No. 31 Tahun 1999 ini masih tetap menggunakan asas pembuktian yang sama dengan yang telah ditetapkan dalam undangundang sebelumnya (UU No. 3 Tahun 1971), yaitu bahwa yang wajib membuktikan suatu tuduhan korupsi pada prinsipnya tetaplah Jaksa Pẹnuntut Umum, bukan terdakwa. Prinsip inipun selanjutnya juga masih tampak dipertahankan UU No. 20 Tahun 2001 sebagai hasil perubahan atas UU No. 31 Tahun 1999.

Sebenarnya, jika ketentuan Pasal 28 UU No. 31 Tahun 1999 disimak dengan cermat, maka dapat dikatakan bahwa undang-undang ini telah mengakomodasikan "embrio" dari konsep mengenai masalah pembuktian terbalik. Sebab, pasal tersebut menegaskan untuk kepentingan penyidikan, tersangka wajib memberi keterangan tentarig seluruh harta bendanya dan harta benda istri atau suami, anak, atau harta benda setiap orang termasuk korporasi yang diketahui dan atau yang diduga mempunyai hubungan dengan tindak pidana korupsi yang dilakukan tersangka (garis bawah dari penulis). ${ }^{16}$ Kalimat "tersangka wajib memberi keterangan tentang seluruh harta bendanya ......dst" dalam rumusan pasal tersebut dapat dimaknai bahwa ia wajib membuktikan hal yang sebaliknya mengenai tuduhan korupsi yang dikenakan penyidik atas dirinya. Konsep pembuktian yang demikian sesunguhnya dapat "dibaca" sebagai awal darj penerimaan undang-undang korupsi terhadap gagasan penerapan asas pembuktian terbalik.

Pasal 28 di atas selanjutnya lebih dipertegas lagi oleh ketentuan Pasal 37 terutama pada ayat (2) yang sekarang pun tetap menjadi Pàsal 37 ayat (2) UU No. 20 Tahun 2001. ${ }^{17}$ Adapun isi dari ketentuan pasal

${ }^{14}$ Soeparman. "Pelaksanaan Pemberantasan Korupsi Berdasarkan UU No.31 Tahun 1999, UU No. 20 Tahun 2001 dan Peraturan Perundangan Lainnya." Makalah dalam Seminar Nasional tentang Analisis Kritis terhadap Eksistensi. Perundang-undangan Pemberantasan Tindak Pidana Korupsi. Diselenggarakan oleh Fakultas Hukum UNS. Surakarta. 8 Mei 2002. HIm. 2.

${ }^{15}$ Lihat Direktorat Jenderal Peraturan Perundang-undangan. 2001. Himpunan Peraturan Perundangundangan tentang Pemberantasan Tindak Pidana Korupsi. Jakarta: Direktorat Kerjasama Publikasi. Direktorat Jenderal Peraturan Perundang-undangan. Departemen Kehakiman dan HAM RI. HIm. 34.

${ }^{16}$ Dalam Undang-Undang Korupsi yang lama No. 3 Tahun 1971, ketentuan di atas termaktub dalam Pasal 6.

${ }^{17}$ Dalam UU No. 31 Tahun 1999, ketentuan Pasal 37 tersebut secara lengkap terdiri atas 5 (lima) ayat. Namun setelah mengalami amandemen oleh UU No. 20 Tahun 2001, pasal ini dipecah menjadi dua ketentuan yaitu menjadi: Pertama, Pasal 37 saja (yang berisi Pasal 37 ayat (1) dan ayat (2) UU No. 31 Tahun 1999 dengan sedikit perubahan redaksional) dan kedua, Pasal 37 A (yang berisi Pasal 37 ayat (3), (4) dan (5) UU No. 31 Tahun 1999 juga dengan sedikit perubahan redaksional). 
dan ayat tersebut pada intinya menetapkan, jika berdasarkan pemberian keterangan itu pada akhirnya terdakwa benar-benar mampu membuktikan bahwa ia memang tidak melakukan tindak pidana korupsi, maka pembuktian tersebut akan dipergunakan oleh pengadilan sebagai dasar untuk menyatakan bahwa dakwaan jaksa tidak terbukti. Secara hukum, konsekuensi dari lahirnya pernyataan pengadilan seperti ini adalah dikeluarkannya putusan yang membebaskan terdakwa dari segala tuduhan.

Berdasarkan konstruksi berpikir yuridis seperti ini, maka sangat wajar jika di depan dikatakan bahwa secara "embrional" UU No. 31 Tahun 1999 sebenarnya telah mengakomodasikan gagasan mengenai penerapan asas pembuktian terbalik. Karena tersangka/terdakwa memikul beban kewajiban untuk membuktikan hal yang sebaliknya dari apa yang telah dituduhkan oleh penyidik maupun penuntut umum kepada dirinya dengan implikasi yuridis jika hal itu mampu dilakukan oleh terdakwa, maka ia akan dibebaskan dari segala tuduhan.

Namun, kesimpulan di atas ternyata tidak sepenuhnya benar. Sebab masih menurut Pasal 37 terutama pada ayat (3), (4) dan (5) yang sekarang menjadi Pasal 37 A UU No. 20 Tahun 2001, dinyatakan bahwa kewajiban terdakwa untuk memberi keterangan tentang asal usul harta bendanya, harta benda istrinya, anaknya, orang lain atau suatu korporasi dalam rangka menolak tuduhan korupsi yang dikenakan oleh jaksa, secara yuridis tidaklah menghapuskan kewajiban prinsipil bagi jaksa untuk tetap membuktikan dakwaannya. Sekalipun berdasarkan keterangan yang diberikan itu terdakwa mampu membuktikan bahwa seluruh harta benda miliknya, milik istrinya dan seterusnya tadi adalah diperoleh dari sumber-sumber yang sah (tidak merupakan hasil korupsi). ${ }^{18}$

Jadi, berdasarkan ketentuan di atas dapat ditafsirkan bahwa jika dalam tahap penyidikan suatu kasus korupsi baik yang dilakukan oleh polisi, jaksa ataupun oleh gabungan keduanya, tersangka dapat membuktikan secara sah kepada penyidik mengenai asal usul harta benda miliknya, milik istrinya dan seterusnya itu, maka berkas perkara tersangka tersebut tetap akan dikirim kepada penuntut umum untuk dibuktikan di persidangan pengadilan. Terlebih lagi jika tersangka sama sekali tidak mampu melakukan pembuktian mengenai hal di atas, maka penerusan berkas perkaranya ke pengadilan tentu merupakan sesuatu yang wajar bahkan memang seharusnya.

Kemudian jika sesudah sampai di persidangan pengadilan pun terdakwa masih tidak mampu juga membuktikan legalitas dari harta benda miliknya, milik istrinya dan seterusnya, maka hal inipun tidak lantas menjadikan ia dapat dijatuhi pidana tertentu sebagai koruptor. Karena secara yuridis, ketidak mampuan terdakwa dalam pembuktian tersebut hanya akan dipergunakan oleh pengadilan untuk memperkuat alat bukti yang sudah ada bahwa terdakwa telah melakukan tindak pidana korupsi. ${ }^{19}$ Jadi

${ }^{18}$ Oemar Seno Adjie. 1983. Hukum Pidana Pengembangan. Jakarta: Erlangga. HIm. 228-229.

19L.ihat ketentuan Pasal 37 ayat (4) UU No. 31 Tahun. 1999 atau Pasal 37 A ayat (2) UU No. 20 Tahun 2001. 
bukan sebagai satu-satunya alat bukti yang bersifat otomatis untuk dapat mempidana terdakwa (sebagaimana yang lazim dalam penerapan asas pembuktian terbalik). Lebih dari itu, dalam hal di atas (yaitu dalam hal terdakwa tidak mampu membuktikan sebaliknya dari apa yang dituduhkan jaksa), menurut Pasal 37 ayat (5) UU No. 31 Tahun 1999 yang sekarang telah menjadi Pasal $37 \mathrm{~A}$ ayat (3) UU No. 20 Tahun 2001, Jaksa Penuntut Umum tetap dibebani kewajiban untuk membuktikan dakwaannya.

Menurut Wakil Jaksa Agung Soeparman, diharuskannya jaksa untuk tetap membuktikan dakwaannya tersebut adalah mengandung maksud agar jaksa dalam requisitoir "yang diajukannya dalam persidangan dapat menuntut supaya harta benda terdakwa dapat dirampas untuk negara melaluj putusan hakim. ${ }^{20}$

Berdasarkan keterangan yang merujuk pada beberapa ketentuan pasal perundangundangan korupsi di atas, maka banyak ahli hukum pidana Indonesia yang menyatakan bahwa dalam penyelesaian kasus kejahatan korupsi, sebenarnya sistem hukum Indonesia tidak menggunakan asas pembuktian terbalik yang bersifat murni sebagaimana yang berlaku di Malaysia atau Singapura, tetapi menerapkan asas pembuktian terbalik yang bersifat tidak murni atau seimbang. Dikatakan demikian karena baik jaksa maupun terdakwa sama-sama menerima beban kewajiban pembuktian dalam pengertian sébagaimana telah dikemukakan di atas. ${ }^{21}$

Patut dikemukakan di sini bahwa konsep pembebanan kewajiban pembuktian yang diatur dalam undang-undang korupsi di atas memang mencerminkan kerancuan regulasi sekali gus inkonsistensi. Sebab pada satu sisi ditegaskan, jika terdakwa mampu membuktikan bahwa tuduhan jaksa tidak benar, maka kemampuan terdakwa"tersebut akan dijadikan dasar (secara otomatis) oleh pengadilan untuk memutus bebas dirinya. Jadi seolah-olah begitu terdakwa mampu membuktikan ketidak benaran dakwaan jaksa, maka usaha pembuktian dakwaan yang dilakukan oleh jaksa menjadi tidak memiliki arti sama sekali. Namun sebaliknya, pada sisi yang lain jika terdakwa tidak mampu menampik dakwaan jaksa dengan membuktikan bahwa dakwaan itu sama sekali tidak benar, maka ketidakmampuannya ini

${ }^{20}$ Soeparman. Op Cit. HIm. 20-21

${ }^{21}$ Beberapa pendapat ahli di atas antara lain dapat dicermati dàri pikiran Bambang Poernomo. Bambang Purnomo. 1984. Pertumbuhan Hukum Penyimpangan Di Luar Kodifikasi Hukum Pidana, Jakarta: Penerbit Bina Aksara. HIm. 80-83. Lihat juga Loebby Logman. 1991. Beberapa Ikhwal tentang Undangundang Pemberantasan Tindak Pidana Korupsi. Jakarta: Tanpa Nama Penerbit. Hlm. 42-47. Selanjutnya hal senada juga dapat diperiksa dari komentar Andi Hamzah. Andi Hamzah. 1984. Pengantar Hukum Acara Pidana Indonsia. Jakarta: Penerbit Ghalia Indonesia. Hllm 22-23 Andi Hamzah. "Perbandingan Antara UU No. 3/1971 dan UU No. 31/1999 Yang Telah Diubah dan Ditambah dengan UU No. 20/2001." Makalah disampaikan dalam Seminar tentang Sosialisasi/Pemahaman Undang-undang Pemberantasan Tindak Pidana Korupsi, Diselenggarakan oleh Kanwil Departemen Kehakiman dan HAM Daerah Istimewa Yogyakarta, tanggal 5 juni 2002. HIm. 6-8. 
hanya dijadikan sebagai salah satu penguat terhadap bukti kebenaran korupsi yang telah ada sebelumnya. Jadi tidak otomatis menjadi dasar oleh pengadilan untuk menyatakan keterbuktian tindak pidana korupsi yang dituduhkan kepada terdakwa. Dengan kata lain, dalam kasus yang demikian usaha pembuktian dakwaan yang dilakukan oleh jaksa sungguh masih sangat berarti dan berperan penting dalam penentuan terbukti tidaknya tindak pidana korupsi yang dituduhkan. Konsep seperti ini tentu sangat berbeda dengan yang telah disebutkan di atas, dan inilah yang dikatakan di depan sebagai regulasi konsep yang rancu dan inkonsisten.

Sebenarnya ada sebagian pandangan yang mengemukakan bahwa konsep seperti tersebut di atas tidaklah harus "dibaca" sebàgai regulasi hukum yang rancu dan inkonsisten, akan tetapi lebih merupákan suatu bentuk kompromi dari "tarik menarik" antara kepentingan individual untuk tetap melindungi hak asasi terdakwa (sesuai asas presumption of innocence) dengan kepentingan umum untuk secara cepat dan tepat dapat menyelamatkan keuangan dan perekonomian negara yang digagas melalui penerapan asas pembuktian terbalik. ${ }^{22}$

Terlepas dari semua yang telah diuraikan di atas, satu hal yang pasti ialah bahwa sampai dengan lahirnya UU No. 20 Tahun 2001 sebagai undang-undang korupsi yang paling mutakhir dimiliki Indonesia, ternyata belum pernah ada satu pasalpun yang secara tegas (eksplisit) menunjukkan telah diterimanya ajaran asas pembuktian terbalik ini. Khususnya dalam pengertiannya yang murni. Padahal gagasan tersebut sudah banyak dibicarakan dan sudah lama diharapkan masyarakat luas agar dapat segera menjadi salah satu basis hukum bagi upaya pemberantasan korupsi yang semakin memprihatinkan. Di samping itu, berdasarkan riset komparatif di beberapa negara tetangga seperti Malaysia, Singapura, dan Hongkong, ternyata penerapan asas pembuktian terbalik ini sungguh efektif sebagai upaya utama yang sangat menjanjikan dalam keberhasilan memberantas kejahatan korupsi. ${ }^{23}$

Oleh karena itu, dalam rangka mewujudkan reformasi lanjutan di bidang hukum, patut kiranya gagasan penerapan asas pembuktian terbalik ini terus menerus didengungkan sebagai wacana publik hingga akhirnya dapat berhasil diakses menjadi salah satu ketentuan perundang-undangan tentang pemberantasan tindak pidana korupsi di Indonesia.

\section{Pemecahan Masalah terhadap Masalah Asas Pembuktian Terbalik}

Berdasarkan analisis mengenai urgensi penerapan asas pembuktian terbalik, kemudian dikaitkan dengan berbagai problem

22Bambang Poernomo. Pertumbuhan Hukum Penyimpangan ..... Op. Cit. Hlm. 81.

${ }^{23}$ Riset tersebut pernah dilakukan oleh Baharuddin Lopa. Baharuddin Lopa. "Mencegah dan Memberantas Korupsi." Kompas. 21 Juli 1997. 
yang menyertainya dan sekaligus memperhatikan regulasi hukum dalam perundang-undangan yang ,telah menampung gagasan tentang asas tersebut, maka sebagai penutup, tulisan ini hendak menawarkan beberapa pemikiran.

Mengingat problem utama berkait dengan penerapan asas pembuktian terbalik adalah bermuara pada terjadinya benturan antara orientasi untuk melindungi kepentingan umum (c.q penyelamatan keuangan/ perekonomian negara) dengan orientasi untuk melindungi kepentingan individu (c.q hak asasi tersangka/terdakwa korupsi), maka pengaturan asas tersebut dalam revisi undangundang korupsi ke depan harus:

a). Ditempatkan sebagai suatu asas yang benar-benar eksepsional, sehingga penyimpangan-penyimpangan yang diatur di dalamnya dapat diterima secara universal sebagaimana layaknya sebuah hukum penyimpangan.

b). Didasarkan atas analisis mengenai keuntungan dan kerugian yang masih berkategori "wajar/dapat ditoleransi" yang sekiranya harus ditanggung oleh individu pelaku korupsi maupun oleh masyarakat luas/negara.

c). Didasarkan atas hasil jajak pendapat berskala nasional untuk melihat tingkat persetujuan masyarakat. Adapun urgensinya ialah untuk menakar keabsahan sosiologis dari suatu aturan hukum yang akan ditetapkan.

d). Diformulasikan dengan bentuk bahasa dan substansi hukum yang sekiranya masih berada dalam koridor penghormatan hak asasi manusia. Untuk kepentingan ini, maka konsep rumusan tentang pembuktian terbalik dalam revisi undang-undang korupsi ke depan perlu dikonsultasikan terlebih dahulu ke KOMNAS HAM untuk memastikan bahwa rumusan tersebut tidak melanggar HAM, atau setidaktidaknya telah mencerminkan perlindungan HAM yang seimbang baik terhadap individu pelaku korupsi maupun térhadap masyarakat luas/negara.

e). Diadakan pengaturan pembatasan sebagai rambu-rambu pengaman agar implementasi asas ini tidak melahirkan berbagai macam risiko negatif sebagai side effect. Misalnya asas ini hanya diterapkan pada kasus-kasus korupsi dengan kriteria terteritu yang berindikasi sangat sulit dibuktikan, atau pada kasuskasus korupsi yang berdasarkan bukti awal diduga telah merugikan keuangan negara dalam jumlah tertentu yang predictable akan "menggoncangkan" perekonomian' negara dalam arti luas dan lain sebagainya.

Sebelum asas pembüktian terbalik ini benar-benar ditetapkan dan dapat dilaksanakan sebagai sebuah ketentuan hukum, maka perlu kiranya diterapkan suatu kebijakan pra conditioning untuk memastikan bahwa seluruh jajaran aparat penegak hukum baik kepolisian, kejaksaan maupun pengadilan, secara relatif harus sudah dapat dikatakan "bersih" dan berintegritas moral yang tinggi. Kebijakan semacam ini diperlukan mengingat pengalaman law enforcement (penegakan hukum) korupsi selama ini telah memperlihatkan fakta yang tidak efektif di mana salah satu penyebabnya antara lain ialah karena aparat penegak hukum sendiri telah 
terkontaminasi oleh "virus" korupsi melalui fenomena: yang populer disebut "mafia peradilan".

\section{Simpulan}

Menyibak kepada permasalahan asas pembuktian terbalik dalam penyelesaian kasus kejahatan korupsi, maka asas pembuktian terbalik sangat relevan. Meskipun penerapannya sendiri perlu dikaji agar kepentingan HAM Dan kepentingan publik tidak menimbulkan benturan yang berakibat kepada ketidakefektifan dari asas tersebut. Di samping itu apabila asas pembuktian terbalik ini akan diterapkan sangatlah perlu untuk dilakukan praconditioning agar tujuan yang diharapkan dari pemberantasan korupsi dapat dicapai. $\square$

\section{Daftar Pustakà}

Adjie, Oemar Seno. 1983. Hukum Pidana Pengembangan. Jakarta: Erlangga.

Al-Attas, Syed Hussein. 1986. Sosiologi Korupsi: Sebuah Penjelajahan dengan Data Kontemporer. Jakarta: Penerbit LP3ES.

Ali, Achmad. "Korupsi dan Asas Pembuktian Terbalik." Kompas. 3 April 2001.

BPKP. 1999. Strategi Pemberantasan Korupsi Nasional. Jakarta: BPKP. HIm. 142-149.

Direktorat Jenderal Peraturan Perundangundangan. 2001. Himpunan. Peraturan Perundang-undangan tentang Pemberantasan Tindak Pidana Korupsi. Jakarta: Direktorat
Kerjasama Publikasi. Direktorat. Jenderal Peraturan Perundangundangan. Departemen, Kehakiman dan HAM R!.

Guwandi, J.. "Pembuktian Terbalik." Kompas 7 April 2001.

Hamzah, Andi. "Perbandingan Antara UU No. 3/1971 dan UU No. 31/1999 Yang Telah Diubah dan Ditambah dengan UU No. 20/2001." Makalah disampaikan dalam Seminar tentang Sosialisasi / Pemahaman Undang-undang Pemberantasan -Tindak Pidana Korupsi, Diselenggarakan oleh Kanwil Departemen Kehakiman dan HAM Daerah Istimewa Yogyakarta, tanggal 5 juni 2002.

-1984. Pengantar Hukum Acara Pidana Indonsia. Jakarta: Penerbit Ghalia Indonesia.

Lopa, Baharuddin. "Mencegah dan Memberantas Korupsi." Kompas. 21 Juli 1997.

Loqman, Loebby. 1991. Beberapa Ikhwal tentang Undang-undang Pemberantasan Tindak Pidana Korupsi. Jakarta: Tanpa Nama Penerbit.

Noeh, Munawar Fuad. 1997. Islam dan Gerakan Moral Anti Korupsi, Jakarta: Penerbit Zikrul Hakim.

Poernomo, Bambang. 1984. Orientasi - Hukum Acara Pidana Indonesia. Yogyakarta: Bagian Penerbitan Fakultas Hukum Universitas Gadjah Mada. 
1984. Pertumbuhan Hukum Penyimpangan Di Luar Kodifikasi Hukum Pidana, Jakarta: Penerbit Bina Aksara.

Poenwadarminta, W.J.S. 1978. Kamus Umum Bahasa Indonesia. Jakarta: Penerbit Balai Pustaka.

Prinst, Darwan. 2002. Hukum Acara Pidana dalam Praktek. Cetakan Ketiga (edisi revisi). Jakarta: Penerbit Djambatan bekerjasama dengan YLBHI.

Soeparman. "Pelaksanaan Pemberantasan Korupsi Berdasarkan UU No.31. Tahun 1999, UU No. 20 Tahun 2001 dan Peraturan Perundangan Lainnya." Makalah dalam Seminar Nasional tentang Analisis Kritis terhadap Eksistensi Perundang-undangan Pemberantasan Tindak Pidana Korupsi. Diselenggarakan oleh Fakultas Hukum UNS. Surakarta. $8 \mathrm{Mei}$ 2002.
Soerjadi, Trimoelja D. " Pembuktian Terbalik Untuk Memberantas KKN?"

Forum Keadilan. Edisi No. 7 tahun VI, tanggal 14 Juli 1997.

Suara Merdeka .22 Maret 2001.

Kompas. 9 April 2001.

UU No. 14 Tahun 1970 tentang Pokok-pokok Kekuasaan Kehakiman.

UU No. 35 Tahun 1999 tentang Perubahan Atas UU No. 14 Tahun 1970.

UU No. 8 Tahun 1981 tentang Kitab Undangundang Hukum Acara Pidana.

Eks UU No. 3 Tahun 1971 tentang Pemberantasan Tindak Pidana Korupsi

UU No. 31 Tahun 1999 tentang Pemberantasan Tindak Pidana Korupsi.

UU No. 20 Tahun 2001 tentang Perubahan Atas UU No. 31 Tahun 1999. 